\title{
Kernos
}

Revue internationale et pluridisciplinaire de religion grecque antique

$9 \mid 1996$

Varia

\section{Religious and Socio-Political Implications of Mortuary Evidence}

Case Studies in Ancient Greece

\section{Eleni Georgoulaki}

\section{(2) OpenEdition \\ Journals}

Electronic version

URL: http://journals.openedition.org/kernos/1160

DOI: $10.4000 /$ kernos. 1160

ISSN: 2034-7871

Publisher

Centre international d'étude de la religion grecque antique

Printed version

Date of publication: 1 January 1996

ISSN: 0776-3824

Electronic reference

Eleni Georgoulaki, "Religious and Socio-Political Implications of Mortuary Evidence », Kernos [Online],

9 | 1996, Online since 21 April 2011, connection on 20 April 2019. URL : http://

journals.openedition.org/kernos/1160; DOI : 10.4000/kernos.1160 
Kernos, 9 (1996), p. 95-120.

\title{
Religious and Socio-Political
}

\section{Implications of Mortuary Evidence:}

\author{
Case Studies in Ancient Greece*
}

\section{Introduction}

Among the ancient people the sacred rituals, i.e. special gestures or acts and offerings, have always been a point of interaction between man and the divine and emphasised their asymmetrical relationship; the two levels could be called Our world and the Other world.

Another occasion when we come into contact with the Other World is at death. Since death is a universal event, the matters related to it are of greatest significance to every man irrespective of time. Religious beliefs inevitably bear used below:

In addition to the standard abbreviations given in L'Année Pbilologique, the following are

BURKERT, Greek Religion: W. BURKERT, Greek Religion, Harvard Univ. Press, 1985.

GARLAND, Greek way of death: R. GARLAND, The Greek way of death, London 1985.

GARLAND, ABSA, 77 (1982): R. GARLAND, A first catalogue of Attic peribolos tombs, in ABSA, 77 (1982), p. 125-176.

KURTZ-BOARDMAN, Burial customs: D.C. KURTZ-J. BOARDMAN, Greek burial customs, New York, 1971.

MORRIS, Ancient society: I. MORRIS, Burial and ancient society, Cambridge, 1987 (New studies in Arcbaeology).

MORRIS, Death in Classical antiquity. I. MORRIS, Death-ritual and social structure in Classical Antiquity, Cambridge, 1992 (Key themes in Ancient History).

SHAPIRO, AJA, 95 (1991): H.A. SHAPIRO, The Iconography of Mourning in Athenian Art, in AJA, 95 (1991), p. $629-656$.

STUPPERICH, Staatsbegrabnis: R. STUPPERICH, Staatsbegräbnis und Prtvatgrabmal im klassischen Athen, Münster, 1977.

STUPPERICH, The Archaeology of Athens and Attica under the Democracy. R. STUPPERICH, The Iconography of Athenian State Burials in the Classical pertod, in W.D.E. COULSON, O. PALAGIA, T.L. SHEAR, H.A. SHAPIRO, F.J. FROST (eds.), The Archaeology of Athens and Attica under the Democracy. Proceedings of an International Conference celebrating 2500 years since the birth of democracy in Greece, beld at the American School of Classical Studies at Athens (4-6 December 1992), 1994 (Series Oxbow Monographs, 37), p. 93-103.

1 See the introduction of C. RENFREW in the publication of the sanctuary at Phylakopi (The Arcbaeology of cult; the sanctuary at Pbylakopt, 1985 [ABSA Supplement 18]). On the sacred ritual, see also W. BURKERT, Homo necans. Interpretation altgriechischer Opferriten und Mythen, Berlin, 1972. 
also on the problem of death, whereas the funeral, by definition, is a ritual activity ${ }^{2}$.

Consequently, an important but not the only task of the historian is the comprehension of the religious ideas related to death. However, the mortuary analysis covers not only the study of the religious aspect of death but also of the material remains which constitute the visible traces of the funerary behaviour of ancient people. The preparation of the disposal facility, the treatment of the bodies, and the kinds and quantities of grave goods represent the stages of the burial procedure and constitute the technical aspect of mortuary bebaviour. These practices are transformed into mortuary ritual, that is to say a mode of communication (acts or gestures), by means of which the living deal with the dead.

In fact, the mortuary system is multidimensional and the burial remains can be approached at different levels, whereas various aspects of life can be studied through death. The ideology hidden behind specific practices may be multi faceted ${ }^{3}$ and the hardest work of the historian is to identify and interpret the symbolism of the mortuary rites. A rite can be studied through direct observation or participation into it, verbal testimony, artistic representations and the material remains. Concerning the Ancient Greek rites the first class is unavailable. Contemporary literature, even if it is plentiful is not very explicit, since funerary rites were so familiar that ancient authors mention them only indirectly and rarely offer explanation. The iconography can be used to explain the literary evidence (i.e., death representations are depicted on Athenian vases, coming from not well-documented contexts). Finally, the archaeological remains permit us to reconstruct the various symbols in concrete actions; this material affords a supplement to the literary and epigraphic evidence ${ }^{4}$.

Earlier scholars invoked the religious beliefs as the only impulse of the mortuary practices. Problems arise still nowadays because we often confuse the secular with the religious meaning of the burial remains or the rank differences reflected in the funerary behaviour with the actual religious beliefs. A satisfactory approach of funerary evidence should be based upon a balanced view of social and religious constraints.

In this paper, by means of a comparative analysis of funerary data from a sample of sites, we try to relate these data to patterns of religious and sociopolitical behaviour within the Ancient Greek society. Certainly, there is no space to examine the ancient burials throughout Greece. Moreover, since a detailed study of burial customs is not so important for the purposes of the

2 R. CHAPMAN, \& K. RANDSBORG, Approacbes to the Arcbaeology of Death, in R. CHAPMAN, I. KINNES, K. RANDSBORG (eds), The Archaeology of Death. New Directions in Arcbaeology, Cambridge, 1981, p. 1; RENFREW, op. cit. (n. 1), p. 17; MORRIS, Death in Classical antiquity, p. 9-10.

3 L. GOLDSTEIN, One-dimensional archaeology and multi-dimensional people: spatial organisation and mortuary analysis, in R. CHAPMAN et alli, op. cit. (n. 2), p. 57.

4 KURTZ-BOARDMAN, Burial customs, p. 142; MORRIS, Deatb in Classical antiquity, p. 10-14. 
present paper, among the abundant bibliography, we refer only to synthetic works.

\section{Religious approach of mortuary behaviour}

It comprises the study of the interaction between the religious ideas and the mortuary behaviour as a whole.

\section{Funerary beliefs ${ }^{5}$}

To comment on how the Greek felt when dying is not an easy task. In fact, burial rites did not really change fundamentally throughout antiquity, but beliefs as to what happened to a person at the point of death and afterwards remained a subject for debate. The available data attest a lack of any universally accepted ideas on the subject. However, it is also true that this matter was not so much a question of independent beliefs but rather a nexus of interrelated ideas. The Greeks themselves did not see a conflict between the mythological views of the early poets and the later ideas of philosophers and Mystery cults ${ }^{6}$.

In the Homeric poems the soul goes down to Hades, a kingdom of fluttering shadows which resemble their bodily forms but have no real life. Odysseus had a vision of scenes inside the Underworld in which the dead were punished for crimes committed in their lifetime. Actually, this is the only mention in Homer of punishment after death ${ }^{7}$.

Later, the mock-stories told by Plato which deal with retributive punishment disturb a man's soul with the possibility that they might be true. In a famous passage, the aged Kephalos states that when a man gets to the point of death, he is afraid of what lies ahead. Moreover, the most complete expression of faith in retributive punishment occurs in Gorgias. "Socrates narrates how in former times, when men were judged while still alive by living judges, false verdicts were being given since their souls were veiled by physical beauty or wealth. Consequently Zeus decreed that the souls should be judged naked after death by Minos, Radamanthys and Aiakos".

R. Garland wonders how representative of non-philosophical Greeks was the view ascribed to Kephalos. In regard to Greek beliefs in the afterlife, "it is generally accepted that an existence confined to the grave represents the earliest stage of eschatological speculation". The moral connotations were

5 This matter has been extensively discussed for several decades, so it is beyond our intention to study it in detail. Still, in order to clarify the religious and socio-political patterns of mortuary data, we will make a brief discussion and mention some of the most important studies related to the topic.

6 N.J. RICHARDSON, Early Greek views about life after death, in P.E. EASTERLING-J.V. MUIR (eds.), Greek Religion and Society, Cambridge, 1985, p. 50, 64, 65.

7 Od., XI, 495, 568-635; see also, $l l$., III, 278-279; RICHARDSON, art. cit. [n. 6], p. 53-54.

8 GARLAND, Greek way of death, p. 17, 66; see also PLATO, Rep., I, 330d-e; Gorg., 523c. 
emphasised by the Mystery cults ${ }^{9}$. According to the same author, religiosity offered the Greek man "a means of worldly assistance in which contemplation of the afterlife" does not seem to have played an important role. If one had acted disrespectfully towards the gods, one did not have to wait until the afterlife to be punished: it was during earth life that the gods would withhold their favours. Fear, Hades was the place of darkness, combined with fatalism, seems to be the worst that the majority of Greeks had to cope with ${ }^{10}$.

The above suggestion seems to be reinforced by the fact that in the funerary art there is a suppression of myth and divinities in favour of the expression of grief or the depiction of the dead as in life. Most of the Attic funerary lekythoi of the fifth century show family members visiting the tomb, where often they encounter a kind of epiphany of the dead, sitting on his tomb (Plate 1). The pathetic status of the deceased vis-à-vis the living is illustrated in the iconography: his/her soul is represented as a diminutive creature hovering plaintively near the grave (Plate 2$)^{11}$.

Moreover, in epitaphs the dead address the living as though still alive and have no clear conception of their differing status. Furthermore, the deceased evoked pity rather than fear to the living ${ }^{12}$. We read on an Attic 6th century

9 Hades could be a later conception, which overtook a former belief (GARLAND, Greek way of death, p. 66, 119). N. Richardson argues that there is a difference between the Homeric idea of the soul as a shadow or image of the body, and Plato's insistence that the soul represented the real personality. The same author suggests that the belief in retributive punishment could have been already popular in Homer's time, but the poet chose not to give it any prominence (RICHARDSON, art. cit. [n. 6], p. 54, 64-65). Some poems that were composed in the course of the 6th century were attributed to Orpheus. Various theological notions were put forward (abstention, purification by special rituals etc.) in these poems. On the role of mystery cults, the possibility of a belief to the idea of reincarnation (?) and bibliography to literary sources, see ID., art. cit., p. 59-63. On the privileges of the dead who in lifetime had been initiated at the Eleusis mysteries, see L. FARNELL, Greek Hero-Cults and ldeas of Immortality, Oxford, 1921, p. 346-347.

10 GARLAND, Greek way of death, p. 17, 48.

11 Shapiro in his study about the iconography of mourning, points out that in the Archaic period a common motif in the public commemoration of the male dead in stelai, kouroi and vases was the likening of the dead to the epic heroes. Alternatively, the artists of the Classical period focused on the private aspects of mourning, which fell primarily to women. [AJA, 95 (1991), p. 629656]. On the subject matters of Athenian white-ground lekythoi, see J. BOARDMAN, Atbenian Redfigure vases: the Classical period, London, 1989, p. 131-132. On the grave statuary, see G.M.A. RICHTER, Kouroi: Archaic Greek Maidens, London 1970; ID., Korai: Archaic Greek Youth, London 1968; E. ROHDE, Psyche: le culte de l'âme cbez les Grecs et leur croyance à l'immortalité, Paris, 1952, p. 201 (trans. A. Reymond).

12 KURTZ-BOARDMAN, Burial customs, p. 331-332. The literary sources refer to the epigrams as $\dot{\varepsilon} \lambda \varepsilon \gamma \varepsilon i \hat{\alpha}$ (STUPPERICH, Staatsbegrabnis, p. 12-14). L. FARNELL suggested that two emotions, fear and affection underlain the early Greek tendency of the dead (op. cit. [n. 9], p. 354). But judged overall, the Greek dead were disagreeable rather than malevolent. Categories of the dead to be feared were murderers and their victims. Plato's recommendation in the Laws (873b) that criminals should be buried outside the city with a stone over their head is significant in terms of the superstitions, attached to the murder. Moreover, the offerings ( $\chi \circ \alpha \mathbf{i})$ poured in honour of the murdered Agamemnon are described as "appeasement of the dead" (GARLAND, Greek way of death, p. 6, 12; see also the study of E. VERMEULE, Aspects of Death in Early Greek Art and Poetry, Berkeley and London, 1979). 
epigram: "Whether you are a citizen or a stranger from abroad, pity Tettichos, a good man, as you go by; he lost his fresh youth by death in war. Mourn for him, and go on your way with good fortune"13. While we hold this perspective, we can understand why the tomb-marker $(\mu v \hat{\eta} \mu \alpha)$ was so important: it represented a "memorial" which would preserve the physical appearance of the dead ${ }^{14}$.

On the other hand, the "necessity of conducting burial rites on behalf of the dead, and the corresponding insult to human dignity", if they were omitted,

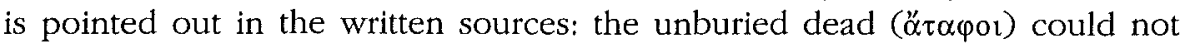
enter Hades but were condemned to haunt the earth. The privilege of the dead ( $\gamma \varepsilon \dot{\varepsilon} \rho \varsigma \theta \alpha v o ́ v \tau \omega v)$ involved lamentation $(\theta \rho \hat{\eta} v o \varsigma)$ and burial. The corpse became sacred through the performance of burial rites and had to be consecrated to the chthonic gods ${ }^{15}$.

\section{Treatment of the body}

It comprises some processes which aim either to the preservation of the organic remains (inhumation) or their destruction (cremation). The inhumation is the practice of burying in the ground. Both environmental and behavioural influences affect the body both before and after burial. The cause of death, the state of the body at death, the time interval between death and either burial or the treatment prior to burial influence its decomposition. On the other hand, since the organic remains are isolated from the surrounding soil environment and animal activity is limited, the decomposition of a body, buried in a coffin

\footnotetext{
$13 I G, \mathrm{I}^{2}, 976$; see also S.C. HUMPHREYs, Family Tombs and Tomb Cult in Ancient Atbens: Tradtion or Traditionalism, in JHS, 100 (1980), p. 103.

14 For further discussion on the grave-markers and bibliographical references, see HUMPHREYS, art. cit. (n. 13), p. 103-104; on the iconography of grave relief, see G.M.A. RICHTER, The Archaic Gravestones of Attica, London, 1961; KURTZ-BOARDMAN, Burial customs, p. 84-88.
}

15 GARLAND, Greek way of deatb, p. 101; see also EUR, Suppl., 524-527, 670; SOPH., Ajax, 11291131; Ant., 453 sq., 1113. The necessity of conducting the mortuary rites was imposed by a nonwritten, divine law; to fail in this duty aroused the anger of the dead, and brought down upon the living divine punishment [RICHARDSON, art. cit. (n. 6), p. 51]. Moreover, to refuse burial even to an enemy of one's state was an abnormal act. The soul of Elpenor, who had been left unwept and unburied implores Odysseus to help him: "Don't abandon me, don't leave me behind, unwept and unburied, lest I become a visitation upon you from the gods" (Od., XI, 72-73; M. ALEXIOU, The ritual

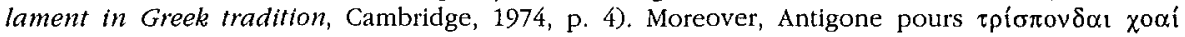
(thrice-poured offerings) to her brother Polynikes as she scatters earth upon his body; in this way she performs some "abbreviated rites" over the corpse (SOPH., Ant., 431; GARLAND, Greek way of death, p. 36). These beliefs attested in the literature, are confirmed by the legislation. In Athens, a law required relatives to "purify the deme" if the corpse had not immediately been buried. Perhaps, immediately after the funeral the Athenians dug a trench near the grave, poured in water

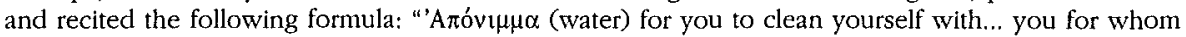
it is meet and right". This rite was intended to benefit both living and dead [STUPPERICH, Staatsbegräbnis, p. 58-59; GARLAND, Greek way of death, p. 42-43, 46-47; KURTZ-BOARDMAN, Burial customs, p. 149-150]; for a detailed discussion about the divinities of the Underworld ( $\chi$ Өóvioı $\theta$ roí), see ROHDE, op. cit. (n. 11), p. 168-177. 
may proceed slower than in the case of an inhumation in the ground ${ }^{16}$. Concerning the cremation, we should keep in mind that once it has finished, the skeleton as a whole exists, though it has been chemically altered as a result of deshydradation; the spongy bones shrink and weigh less than those of an ordinary skeleton ${ }^{17}$.

Both inhumation and cremation were common in Geometric Greece, but in the Archaic period the number of cremated adults increased. In Athens, the most frequent type was the inhumation in a pit, whereas larnax burials became more popular from 450 B.C. onwards. Evidence from Classical period reveals no preference in either way; the choice remained a matter of family preference. Tile graves were very popular, whereas adult inhumations in pithoi were exceptional $^{18}$.

It is not easy to determine whether, or to what extent, variation of the treatment of the body (cremation, inhumation) reflects differences of belief ${ }^{19}$. Actually, this variation might also be related to the social status of the deceased or the circumstances of death. For instance, cremation was convenient for mass burials, after battle or in the extremities of the pestilence in Athens. Kurtz and Boardman note that there is no apparent difference in either the rites or the grave goods and the predominance of one method over the other varies from place to place. Nor can economic factors be held entirely responsible for the choice either, since expensive grave goods have been found associated with inhumations ${ }^{20}$. I. Morris thinks that the ritual system was opening up, allowing a wide range of choices ${ }^{21}$.

Nevertheless, according to the literary sources both cremation and inhumation performed the same function, that means the consecration of the body to the chthonic gods ${ }^{22}$. The cremation might be thought to release the soul from this world more rapidly than inhumation. Still, it is clear that what really mattered was that the body received a proper burial whether this involved cremation or inhumation. Actually, by the deposition of its cremated or inhumed remains

16 A. GARLAND-R. JANAWAY, The Taphonomy of inbumation burials, in R. CHAPMAN et alit, op. cit. (n. 2), p. 15-16, 18, 22, 25-27.

17 J. McKINLEY, Cremations: Expectations, Metbodologtes and Realities, in C.A. ROBERTS, F. LEE, J. BINTLIFF (eds), Burial Archaeology, current research, methods and developments, 1989 (BAR British series 211), p. 266.

18 KURTZ-BOARDMAN Burial customs, p. 71, 73-74, 96; MORRIS, Death in Classical antlquity, p. 140-144; ROHDE, op. clt. (n. 11), p. 185-187.

19 RICHARDSON, att. cit. (n. 6), p. 50.

20 THUC., II, 52; cf. KURTZ-BOARDMAN, Burial customs, p. 96, 190.

21 MORRIS, Deatb in Classical antiquity, p. 140-144.

22 The process of death might be considered as incomplete until the flesh had rotted from the bones (GARLAND, Greek way of death, p. 46-47; KURTZ-BOARDMAN, Burial customs, p. 330). In the Homeric poems, the prevailing view was that when the body has been burnt the soul is free to enter Hades (RICHARDSON, art. cit. [n. 6], p. 50-51; see also Il., XXIII, 71-76; Od., XI, 51-54, 216-222). The body of Klytaimnistra is described as having been rendered $\alpha \gamma$ róv by fire (EUR., Or, 40). 
in the earth, it was believed that since earth was mother of all things, the earth would be repaid for the gift of life and so fertility would be promoted: we read on an a 5 th century B.C. Attic inscription: "He died in the earth where he was nourished"23.

\section{Grave goods}

The objects which were selected to be put into the grave formed integral part of the funeral ceremony. In this paper, we call these items grave goods ( $\kappa \tau \varepsilon \rho i \sigma \mu \alpha \tau \alpha$ ) instead of grave offerings. In fact, the word offering is directly associated with a cult activity, so any attempt to classify the goods in this way prejudges conclusions about their purpose.

However, we could not a priori consider the funerary artefacts as votive offerings, similar to those found at formal shrines. In fact, since no ancient author gives any clear account of the principles involved at the placing of these objects in the tombs, it is likely that the Greeks would have differing reasons for this act: for instance, because an item belonged to the dead person, or he/ she might need it, because the relatives valued it, because they should honour the gods below ${ }^{24}$ or because it served the funerary ritual. In Herodotus, the grave goods were linked to the perceived needs of the dead in the next world $^{25}$. In this context we could call the grave goods accompanying goods.

In inhumation graves, the grave goods were placed inside the burial pit, along the sides of the body or clustered around the head or feet, whereas in cremations they were placed in special pits or ditches near the grave. In Archaic Attica, most of the tombs were furnished with a pouring vessel, whereas metal items were virtually unknown. In Classical period, apart from the vases, most of the grave goods seem to be personal possessions of the dead: strigils (associated with male burials), mirrors, toilet implements (associated mainly with female burials) and toys. Some warriors were buried with their armour. The clay figurines represented known types: seated women, toys, dolls and animals. Regarding the figurines, it is worth noting that there were several representations of mourners; for instance, an archaic figure from a Thera grave represents a woman tearing her hair and cheeks (Plate 3). It seems therefore, that the latter artefacts were made especially for the graves ${ }^{26}$; still, they could

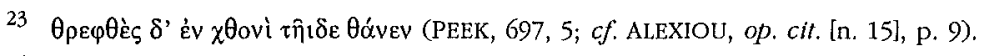

24 KURTZ-BOARDMAN, Burial customs, p. 206.

25 Periander's wife complains from the Underworld that she is cold because her clothes had not been burnt with her (HDT., V, 92, 7; cf. GARLAND, Greek way of death, p. 150).

26 KURTZ-BOARDMAN, Burial customs, p. 71, 75, 101-103, 204, 207-209, 214. Modelled figurines attached to a vase were found at Kameiros; these figurines are dated to the 7 th century and are represented with their hands to their hair and once to the cheeks and in ischia. Moreover, the most famous grave goods would be the obols, the small coins, which from the end of the sixth century onwards, accompanied the dead to pay the ferryman who took them into Hades (MORRIS, Ancient society, p. 47). 
be included to the broad category of accompanying goods. On the other hand, foodstuffs in burials are represented by sea shells, eggs, nuts and the bones of small animals, birds and fish. They are found in the grave itself or in the pyres where the goods were burnt ${ }^{27}$.

\section{Burial rites}

As we have explained, the purpose of the mortuary ritual should be the communication of the living with the dead. The deceased constituted the dead society, towards whom the living had some sacral duties to accomplish.

The funeral $(\kappa \eta \delta \varepsilon i \alpha)$ was a three-act drama comprising the laying out of

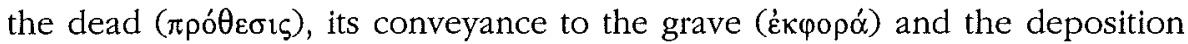
of its cremated or inhumed remains. Kinsmen to the limits of $\dot{\alpha} \gamma \chi 1 \sigma \tau \varepsilon i \alpha$, that is to say bilateral relatives as far as the second cousins, had to perform funeral rites ${ }^{28}$. According to the written sources the prothesis ascertained that the deceased was really dead or confirmed that the dead person had not died violently ${ }^{29}$. However, the iconography contradicts these rationalistic explanations: the mourners are depicted "to sing a funeral song in honour of the dead in order to satisfy the claims of duty" (Plate 4) ${ }^{30}$. Actually, the ritual lament was so important as the burial itself. According to M. Alexiou, the lament was not just a spontaneous outbreak of grief but was carefully controlled in accordance with the funerary rituals at every stage. The tearing of the hair and clothes were not acts of uncontrolled grief but part of an indispensable ritual ${ }^{31}$. Nevertheless,

27 The food and some other goods were burnt (rather than cooked) and thus "killed", so that they could accompany the dead to Hades. It is doubtful whether the burnt deposits, that is to say ashes, animal bones and sherds of bowls and plates, that were found associated with some graves were the remains of the $\pi \varepsilon \rho i \delta \varepsilon ı$ inov mentioned by the literary sources. Of the perideipnon itself we know nothing except that it was an occasion for relatives to gather. The ancient authors allude to the importance of this meal but most imply that it was taken at the home of the dead (Burial customs, p. 146, 215). For further discussion, see GARLAND, Greek way of death, p. 39-40; BURKERT, Greek Religion, p. 193; ALEXIOU, op. cit. (n. 15), p. 7-8.

28 GARLAND, Greek way of death, p. 21. The word $\kappa \eta \delta \varepsilon i \alpha$ meant both "care for the dead" and "relation by marriage". Burial in the family plot was proof of "decent", whereas burial elsewhere was a ground for denying it. "Decent" meant membership of the citizen estate and with it access to land holding and political rights. The heirs were obliged to bury the dead and could be called upon to pay the costs of burial by deme officials, if they did not carry out this obligation (MORRIS, Ancient society, 53-54; see also LYSIAS, 31, 21; ARISTT., Constitution of Atbens, 42, 1). On the other hand, by means of erecting the burial monuments, family unit was also stressed (HUMPHREYs, art. cit. [n. 13], p. 98, 112-113). For further discussion about $\kappa \hat{n} \delta o \zeta$ and $\kappa \eta \delta \varepsilon \sigma \tau \alpha \grave{~[\varepsilon ่ \pi \imath \beta \alpha ́ \alpha \lambda \lambda o v \tau \varepsilon \varsigma] ~ s e e, ~}$ ALEXIOU, op. cit. (n. 15), p. 10-11.

29 For a detailed description of protbesis according to the literary sources see, GARLAND, Greek way of deatb, p. 30; KURTZ-BOARDMAN, Burial customs, p. 143-144; see also PLATO, Laws, XII, 959a; POLLUX, VII, 65.

30 GARLAND, Greek way of death, p. 30; MORRIS, Ancient society, p. 53-54.

31 AlEXIOU, op. cit. (n. 15), p. 4-6. Since grief seeks expression, the lament arises from natural human needs, combined with prevailing popular notions. However, the lamentation in Ancient Greece was sometimes abused. The legislators believed that the lamentation should be dignified and, since women were given to extravagant displays of grief, most of the structures of the legisla- 
both rationalistic and emotional reasons could play an important role for the performance of the prothesis.

On the other hand, while we hold the perspective that the funeral was considered as absolutely necessary for the appeasement of the soul, we cannot a priori assume that all the grave goods represented the deceased's personal possessions (accompanying goods). They could also be contributions, donated by the living. In the latter case, they tend to be highly formalised. Similar vases represent types which are not regularly found in domestic deposits, specifically

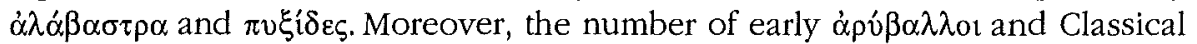
$\lambda \dot{\eta} \kappa v \theta_{0}$ and the later unguentaria found in graves suggests that these vessels were necessary to both the dead and the living. Objects of everyday use (oivo $\chi^{\prime} \alpha_{1}, i \delta \rho i \alpha_{1}$ ) might acquire a funerary significance in the grave, that is to say some pouring vessels might be used for the offering of oil after burial. Moreover, the ancient authors refer to $\chi 0 \alpha \mathrm{i}$ that were made at the grave $\mathrm{e}^{32}$.

Some cemeteries disposed special places for the performance of the mortuary rites. The so-called offering trenches were elongated structures, varying in length from 2 to 12 metres (Fig. 1) ${ }^{33}$. From the discovery of pottery within these structures, we may assume that they were receptacles for the vases that were used during the funerary ceremony.

Besides, some funerary rites were of magic character and imply that the dead were considered as deliverers to chthonic deities: from the late fifth century onwards, the living placed in graves small folded lead plaques known as $\kappa \alpha \tau \alpha \delta \varepsilon \sigma \mu o i ́$ (curse-tablets) (Plate 5) invoking the assistance of Persephone and Hermes. Some tablets contained the names of the person to be cursed ${ }^{34}$.

To sum up, the sacral duties that the living should accomplish towards the dead was first of all showing one's grief in a significant manner (ritual lament). The descendants had also to ensure that the burial was conducted in a decent manner. Finally there was the desire to commemorate the dead in future. The regular visiting of the tombs of one's dead relatives was so important as the

tion were aimed at them [R. RUSCHENBUSCH, $\Sigma O \Lambda \Omega N O \Sigma$ NOMOI, Wiesbaden, 1966, p. 95-97; A. SHAPIRO, AJA 95 (1991), p. 630-631]. It is note worthy that Lucian (On Mourning) said that if the dead person was able to answer the laments of his family he would tell them to stop making fuss, since he is in many ways far better off now than when he was alive (RICHARDSON, art. cit. [n. 6], p. 52-53).

32 KURTZ-BOARDMAN, Burial customs, p. 99, 207-209, 144-146, 205, 210 Pl. 22, 41. This last libation was presented only the third day ( $\tau \dot{\alpha}, \tau \rho i \tau \alpha)$.

33 These structures appear at the end of the 8th century B.C. and become a dominant feature of the cemeteries in the 7 th century, a development that can be easily traced in the Kerameikos cemetery. Judging from the fragments of carbonised wood found inside post-holes, it seems that the offerings were disposed on wooden planks. The trenches were later lined with clay, while three ridges divided it into two channels (GARLAND, Greek way of deatb, p. 36; J. WHITLEY, Tbe Monuments that stood before Maratbon: tomb cult and bero cult in Archaic Attica, in AJA 98 [1994], p. 217-218).

34 GARLAND, Greek way of death, p. 6. 
burial itself. The customary practices performed on behalf of the dead were

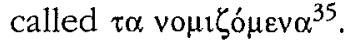

\section{Sociological approach of mortuary behaviour}

Death is a critical event and the transition from life to death might be considered as a continuum in which various processes act. A burial is part of the social circumstances surrounding the biological fact of death. The general relationship between society and burial allows the historian to work back from burials to society, whilst something of the social structure enters the archaeological record through its material manifestations. Moreover, the weight attached to age, sex, wealth, birth or any other quality affect the funerary rites. In fact, there is an increase in the complexity of funerary behaviour going hand in hand with greater emphasis on the already existing funerary rites ${ }^{36}$.

\section{Private burials}

Age discriminations can be detected at many cemeteries: at Argos, adult graves were moved outside the settlement around 700 B.C. Children continued to be provided with some grave goods but adults were not accompanied by any goods. In Athens, child burials in adult cemeteries were common in the end of the Geometric period; in the Archaic period, children were buried separately, in their own cemeteries. The separation of adults and children through different rites and discrete cemeteries was quite common in Archaic Greece. In Classical period, the children were buried in cheap burial containers, that is to say in clay tubs (Fig. 2). The rites affecting the child burials were less exacting and presumably no danger of pollution was feared from lives lost so young. The fear of pollution might be a reason for keeping the main cemeteries outside the town: land within a walled area was too valuable to waste on the dead ${ }^{37}$.

35 RICHARDSON, art. cit. (n. 6), p. 51; GARLAND, art. cit. (n. 34), p. 104; AlEXIOU, op. cit. (n. 15), p. 7-8; ROHDE, op. cit. (n. 11), p. 193-197. The Athenian "all souls' day" was called "the

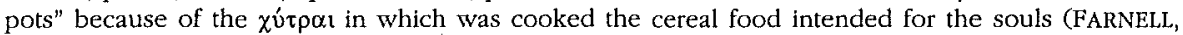
op. cit. [n. 9], p. 344-345). The omission of visiting the tomb of his dead by a heir might be adduced as evidence in a case of disputed inheritance, to prove that the claimant had no genuine kinship with the deceased.

36 The mortuary rites were related to the cultural or social context. For instance, some graves of the 4th and 3rd century BC. in Crete, S. Italy and Thessaly contained gold leaves bearing inscriptions about the afterworld. A "log" in the cremation pyre was a burned papyrus roll. According to this text, these people had a different concept about afterlife than that in "official" Greek religion. The texts are considered to be "Orphic" or "Dionysiac". However, the cremation of the body and the placement of clay vases and jewellery in the tomb meant different things to these people than to other contemporaries. Besides, all other aspects of these tombs were typical of local burial practices (MORRIS, Death in Classical antiquity, p. 17-18; for further discussion and bibliographical references, see MORRIS, Ancient society, p. 29, 31, 34, 36, 40).

37 KURTZ-BOARDMAN, Burial customs, p. 71-72, 97-98, 188-190. On age discrimination, see also MORRIS, Deatb in Classical antiquity, p. 26-29, 186-190. 
On the other hand, burial was an occasion for display of wealth and family pride. Thus, persons of high economic status demonstrated their prestige through the construction of monumental tombs and rich grave goods ${ }^{38}$. Plato quotes a popular view, according to which a Greek man wished to be rich, healthy, honoured by the citizens, and, after burying his parents well, to be buried magnificently ${ }^{39}$.

The iconography suggests that in the Archaic period the ékpop $\alpha$ had been a magnificent, public affair, with the bier carried on a wagon and drawn by horses, followed by kinswomen, professional mourners and armed men ${ }^{40}$. Another index of high energy expenditure accorded to the burial is provided by the cremations: the completeness of the cremation indicates a ceremony lasting many hours ( $c f$. the seventh-century cremations at Thorikos) ${ }^{41}$.

In Archaic period funerary architecture flourished. The differences among the dead in the cemetery of Kerameikos can be recognised in the various types of monumental markers (Fig. 3). The offering trenches, unlike the rest of the offering places, situated simply outside the grave, were associated with fine pottery and elaborate tombs ${ }^{42}$. The differences among the deceased can be further recognised in the Attic mounds ( $\tau$ v $\mu \beta$ ov $)$ (Petreza, Velanideza and Vourva [Fig. 4]). The large size of these mounds encouraged their re-use by members of the same family ${ }^{43}$. Another index of the care accorded to certain burials is provided by the cemeteries at Argos, where there are poor undifferentiated pithos burials alongside with the richer cist graves ${ }^{44}$.

Besides, the tombs' location and the spatial patterns within the cemeteries were deliberate acts. For instance, around 600 B.C., when the problem of space became acute in the Kerameikos, some funerary monuments were superimposed (Fig. 5) ${ }^{45}$. However, before the end of the sixth century the grandeur of funerary monuments was declined and the later monuments were inferior in

38 Grave goods feature less prominently than the grave marker as status symbols in Homeric funerals -Penelope claimed it would be unfitting for Laertes who had won such great possessions to be buried without a finely embroidered winding sheet-, but still served as a medium for statements about the wealth and rank of the deceased (HOMER, Od., XIX, 141-147; MORRIS, Anclent soctety, p. 47).

39 GARLAND, Greek way of death, p. 22; see also PLATO, Mipp. maj., 291d-e.

40 ALEXIOU, op. cit. (n. 15), p. 7 n. 31: Athens 806 (large sepulchral crater showing processions of chariots and mourners, c. 750 BC.), 803 (large burial amphora of the same period, showing the dead man on a horse-drawn, two tiered chariot, followed by mourners), 10682 (geometric amphora showing hoplite procession, c. 750-700 BC.).

41 On cremations at Thorikos, see MORRIS, Ancient society, p. 152-154, 183-184.

42 KURTZ-BOARDMAN, Burial customs, p. 75.

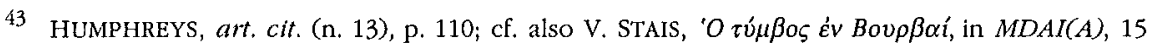

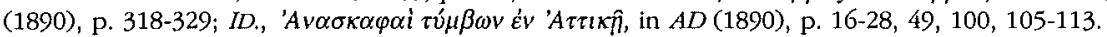

44 For further discussion and bibliographical references, see MORRIS, Ancient society, p. 152154.

45 KURTZ-BOARDMAN, Burlal customs, p. 80; HUMPHREYS, art. cit. (n. 13), p. 106-108. 
quality ${ }^{46}$. Natural causes, such as lack of space, or contemporary political conditions might have determined this development. In fact, since the prestige was defined through sumptuary behaviour and the funerary legislation sought to check the abuses detected at the impressive funerary monuments ${ }^{47}$, the latter suggestion seems most feasible.

The Spartan law was so strict that the dead were not accompanied by any personal belongings ${ }^{48}$. We have explained that the disposal of grave goods in the tomb originated from an established religious belief, i.e. they secured the stay of the dead in another dimension. So, in the case of Sparta the state laws did not simply check the abuses but interfered in the religious thought of the people.

In Classical period, the average Athenian citizens were buried in peribolos tombs, that is to say a group of graves in an enclosed area (Fig. 6). Since these enclosures were intended to be seen from the roadside, less care was devoted to the side walls. The dead might belong to one family ${ }^{49}$. A series of monumental periboloi, probably of the middle of the 5th century were recently discovered at Ramnous. One of them held bases for three stone vases, probably a

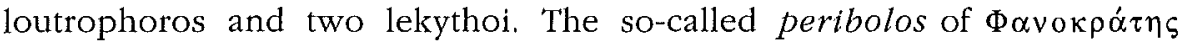
contained 15 burials ( 9 cremation burials, 5 tile graves and 1 pit grave). The Attic funerary monumental architecture of the 4th century can be studied at Kerameikos and Ramnous; at the latter site, a monumental peribolos of the second half of the 4th century, belonging to the rich family 'I 'P $\alpha \mu$ vovoíov, comprised grave relief, stelai and loutrophoroi (Fig. 7) ${ }^{50}$.

46 After the Persian wars archaeological evidence for funerary monuments in Attica almost disappears for about 50 years, with the exception of iconography. Pictures of visits to the tomb on lekythoi show that small individual mounds were built (HUMPHREYS, art. ctt. [n. 13], p. 110).

47 In this context, the reference of Cicero (Legibus, II, 26, 64) regarding Solo's legislation and an inscription from Ioulis of Keos of the 5th century BC. are of interest. On the abuses detected at the burial monuments and the funerary legislation, see X. DE SCHUTTER, Rituel funéraire et colnt des obsèques en Grèce, in Kernos 2 (1989) p. 53-66; R. GARLAND, The Well-Ordered Corpse; An Investigation into the motives bebind Greek funerary legislation, in BICS, 36 (1989), p. 1-15; GARLAND, Greek way of death, p. 137-145; KURTZ-BOARDMAN, Burlal customs, p. 89-90; HUMPHREYS, art. cit. (n. 13), p. 101-102.

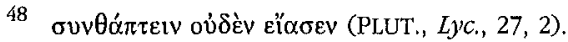

49 In the absence of any firm evidence to the contrary, it is feasible that the practice of erecting a stone or mud-brick burial enclosure began during the fifth century. The Attic peribolo $i$ were circular or rectangular in plan; the tall stele of the tombs were flanked by high relief or freestanding statues of the dead [KURTZ-BOARDMAN, Burial customs, p. 105-108; GARLAND, ABSA, 77 (1982) p. 127-129].

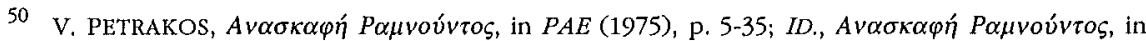
$P A E$ (1976), p. 5-60; ID., in Ergon (1977), p. 3-4; ID., in Ergon (1987), p. 88-89 Pl. 100-102; ID., in Ergon (1988), p. 3 fig. 2-5; ID., in Ergon (1991), p. 6-8 fig. 8-10; ID., in Ergon (1993), p. 1-2 fig. 1; on the peribolos of $\Phi$ ovoxpó $\tau \eta_{\zeta}$, see ID., in Ergon 1989, p. 1 fig. 1. On the Hierokles peribolos, see V. PETRAKOS, P $\alpha \mu v o v \varsigma, A v \alpha \sigma \alpha \alpha \varphi \eta ́$ in Ergon (1977), p. 7-9 fig. 1-2; ID., in Ergon (1985), p. 47 fig. $49-$ 51; ID., in Ergon (1986), p. 94 fig. 64-66; ID., in Ergon (1992), p. 6-7 fig. 6-7. 
Besides, in Attica a deterioration in the quality of vessels, designated for the performance of the funerary ritual can be detected from the Classical period onwards. It is noteworthy that the white-ground lekythos was progressively replaced by some cheaper vessels, that is to say the unguentarium (vessel for holding ointments). However this cut-back in expenditure does not necessarily mean a disinterest in the welfare of the dead. Despite the careless manufacture of the unguentaria, the elevated number of similar artefacts in certain tombs indicates that the mourners wished to make up by numbers for the insignificance of the vessel itself ${ }^{51}$.

\section{Public burials}

After having dealt with the question of the treatment of the ordinary dead, we will pursue investigating how the funerary practices might be modified in the case of deceased, who were regarded as special because of their death circumstances. In several poleis, a differentiation between the public burial and the private burial can be easily traced.

Pericles, in his funeral speech points out that death in battle on behalf of the polis formed such a large part of the social persona that blocked all other considerations. In Classical period, the war dead were given a state-burial in Athens itself in the $\pi$ o $\lambda v \alpha{ }^{\prime} \delta \rho \varepsilon \varepsilon \alpha$ (collective graves), whereas other poleis buried their war dead on the battlefield ${ }^{52}$. When this ceremony ${ }^{53}$, described by

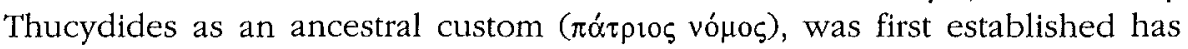
been much debated. R. Stupperich suggests the Kleisthenic reform. C. Clairmont argues that the notion we have about public burial in the period before the 5 th century is largely determined by the written sources. The burials described in Homer and depicted in the iconography were public affairs only in as far as the male community was involved. In contrast, involvement of the city as a governmental institution is lacking and actual remains of $\pi \circ \lambda v \alpha \dot{v} \delta \rho \varepsilon\llcorner\alpha$ are also lacking. Clairmont suggests that in the Archaic period the soldiers who survived would take charge of the dead removing them from the battlefield and carrying the corpses back home; afterwards, the dead would be given to the individual families for fulfilment of the burial. The same author reaches the conclusion that an early form of patrios nomos would be the fulfilment of an unwritten law. In this sense this law might be considered as "sacred". In contrast

51 GARLAND, Greek way of death, p. 37.

52 On the textual evidence regarding polyandrela, see C.W. ClaIRMONT, Patrios Nomos: Public Burial in Athens during the Fifth and Fourth Centuries BC., Oxford, 1983, p. 368-371 (BARIS 161).

53 The social, political and psychological implications of the "Patrios Nomos" have been considered by many scholars, so it is beyond our intention to study these problems in detail; still, we mention some of the most important studies related to this subject: N. LORAUX, L'invention d'Atbènes: bistoire de l'oraison funèbre dans la cité classique, Paris, 1981 (Civilisations et sociêtés 65); GARLAND, Greek way of death, p. 90; KURTZ-BOARDMAN, Burial customs, p. 108-109; CLAIRMONT, op. cit. (n. 52), p. 8-15. 
to this early nomos, Thucydides could later describe in detail what the patrios nomos of Classical period consisted of ${ }^{54}$.

However, hard evidence to support the hypothesis of Clairmont is not easy to find. In fact, assuming that state did not enter as a governmental institution in the war dead burials solely in the absence of detailed descriptions of these ceremonies seems rather simplistic. It is worth noting that what we may interpret as differentiated attitude of the state towards the war dead, may in fact represent a crystallisation in political behaviour through time and an elaboration of public ceremonies in Classical period. This elaboration should also be attested in written sources.

The latter suggestion is reinforced by both the literary references and the archaeological data: according to an epigram attributed to Simonides, the Athenians who died on Euboea, in victory over the Chalkidians, were buried in a $\pi$ o $\lambda v \alpha{ }^{\prime} v \delta \rho \varepsilon v$ at the expense of the Athenian state ${ }^{55}$. Moreover, already in the seventh century, death in battle was a form of achieved status owed to the fallen warrior by the state. It is also noteworthy that the $\pi \rho \cos _{\varepsilon v o r}$ and $\pi \rho \varepsilon \varepsilon \beta \varepsilon ı$ (ambassadors) were entitled to receive a public funeral ${ }^{56}$.

$\mathrm{J}$. Whitley, in a recent study, argues that the mound at Marathon, though simple in form, is a monument that looks both forward to the democracy of the 5 th century and backward to the Archaic period. It "echoes in its design features of much earlier monuments and anticipates forms of public commemoration that were to become current by the time of Pericles" 57 . According to the literary sources, the Athenians at Marathon were buried where they fell and covered by a great mound ${ }^{58}$. However, the ancient authors did not describe these burials in detail. According to the archaeological evidence, the burial mound comprised a central cremation tray $(\Delta)$, containing the remains of the war dead, and an offering-trench with pottery (E) (Fig. 8). Some grave stelai were also found around the mound ${ }^{59}$. No other Archaic mounds with internal cremation trays and external offering trenches have come to light. According to Whitley, the Marathon mound stands out from other contemporary structures,

54 Clairmont, op. cit. (n. 52), p. 7-9, 11. For a detailed discussion, see STUPPERICH, Staatsbegrabnis, p. 219-225; STUPPERICH, The Arcbaeology of Atbens and Attica under the Democracy, p. 94.

55 D.L. PAGE, Epigrammata graeca, Oxford, 1975, 9 line 86.

56 HUMPHREYS, art. cit. (n. 13), p. 102; see also TYRTAEUS, Fr.. 7 West; IG, XI. 1 867. On the ambassadors' graves, see ClAIRMONT, op. cit. (n. 52), p. 260 n. 11.

57 WHITLEY, ait. cit. (n. 33), p. 213.

58 THUC., II, 34.5; HDT., VI, 117, 1; PAUS, I, 29, 4; 32, 3-5. CLAIRMONT argues that since there was the fear of violation of inhumation burials in foreign territory, cremation gave assurance that the bones and ashes were returned for interment in Athens (op. cit. [n. 52], p. 19-20).

59 V. STAIS, $O \varepsilon v M \alpha \rho \alpha \theta \omega ́ v \imath \tau \dot{v} \mu \beta o \varsigma$, in $M D A I(A), 18$ (1893), p. 46-63. Stais pointed out the similarity of the Marathon mound to that of the complex of Vourva, where a mound with cremations and an exterior offering trench with pottery of the end of the 7th century or the beginning of the 6th century were also discovered [WHITLEY, art. ctt. (n. 33), p. 216; $c f$. also supra, Fig. 4: the offering trench is marked by the horizontal bars labelled $\theta$ on either side]. 
because the war dead were not simply buried, but heroized ${ }^{60}$. This suggestion is reinforced by the text of Pausanias, who notes that these dead received heroic honours in the second century A.C. ${ }^{61}$.

Nevertheless, Thucydides' account of the ceremony held on behalf of the citizens who died in the first year of the Peloponnesian War $(2,34)$ suggests that the public funeral in Classical period permitted an extension of customary mortuary rites. In this context, the fact that the protbesis lasted three-days instead of one, whilst wagons instead of pall-bearers were employed to transport the dead to the cemetery and the female relatives attended the funeral is of interest ${ }^{62}$. Furthermore, unlike the domestic vases that were used during the funerary ceremony in the private burials, vases designated for sepulchral rites, especially loutrophoroi, were necessary for the performance of rites on behalf of the war dead, since many soldiers were unmarried. That these vases were prepared specifically for the state burials is confirmed by the iconography ${ }^{63}$. In addition, a passage of Aeschylus lets us conclude that the war dead were not cremated communally but separately ${ }^{64}$. Certainly, weeping was an expression of status at both private and public funerals ${ }^{65}$. Furthermore, funeral

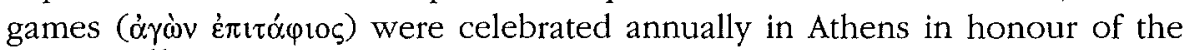
war dead ${ }^{66}$.

The annual celebration in honour of the dead corresponded to $\tau \dot{\alpha}$ $v o \mu$ \ó $\mu \varepsilon v \alpha$ which the family performed on behalf of its dead. The public ceremony differed from the private in being financed by the city and celebrated on a larger scale ${ }^{67}$.

Besides, it is feasible that political factors influenced the location of cemeteries with public burials. According to Thucydides, the Athenians buried their war dead in a suburb of Athens, on both sides of the road leading from the

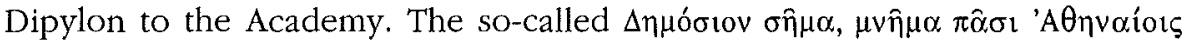

60 WHITLEY, art. cit. (n. 33), p. 215-217.

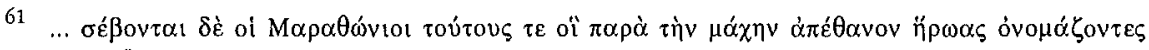
(PAUS., I, 32, 4).

62 GARLAND, Greek way of death, p. 89. In Athens a law attributed to Solo permitted women over the age of sixty and individuals being within the degree of second cousin to enter the house of the dead and to participate in the funeral (ibid., p. 42). The widows and orphans of the war dead were taken care by the demos (STUPPERICH, The Archaeology of Atbens and Attica under the Democracy, p. 100).

63 STUPPERICH, The Archaeology of Athens and Attica under the Democracy, p. 97. On the ceremony, see STUPPERICH, Staatsbegräbnis, p. 32-33.

64 AESCH., Agam., 437 ff.; cf. GARLAND, Greek way of death, p. 92.

65 On the public mourning, see SOLO, Fr.. 21 West; MORRIS, Ancient society, p. 48. The mourning figures shown on "warrior lekythoi" are symbols of the grief felt by the citizens for their casualties (STUPPERICH, The Archaeology of Atbens and Attica under the Democracy, p. 97).

66 ARISTT., A.P., 58, 1; GARLAND, Greek way of death, p. 90; STUPPERICH, Staatsbegrabnis, p. 54-56; ClaIRMONT, op. cit. (n. 52), p. 24.

67 KURTZ-BOARDMAN, Burial customs, p. 112, 121. 
(people's grave) included both $\pi 0 \lambda v \alpha$ ó $\delta \rho \varepsilon 1 \alpha$ and tombs of distinguished individuals. The war graves had altar-like dressed stone monuments topped with statues (Fig. 9). Their names were inscribed on casualties lists, the $\sigma \tau \hat{\eta} \lambda \alpha^{6}{ }^{68}$. It is worth noting that the polyandria relief depicted triumph in battle, not defeat. The beholder was made to believe that success was on the Greek side and defeat fell to the opponent. Moreover, since burying the dead was so important, there were cenotaphs for those who lost their lives far from home; these cenotaphs received offerings like the rest of graves ${ }^{69}$.

An early state grave was that of Lacedaimonians ( $404 / 403$ BC.): 13 men were buried there, some with arrows still lodged in their bodies. In the central chamber, 3 men had been laid out with great care. On the western side of the tomb, there was a series of warriors' graves enclosed within peribolos tombs ${ }^{70}$. In the same context, the peribolos tomb of Dexileos, who died fighting in Corinth at the very beginning of the 4th century is of interest (Fig. 10).

The use of coffins or some other protective device (cover slabs) in cemeteries with multiple burials did not have as purpose to hinder the decomposition of the body but it was rather a mark of individualisation among the rest of the dead. This suggestion is reinforced by the discovery of a larnax of the early fifth century at Corinth which contained armour and a bronze ash $u^{71}{ }^{71}$. In this case the remains of the cremated warrior were placed in a special facility, that is to say the larnax. In view of the greater care that was accorded to the disposal of his remains, we may assume that the warrior was specially honoured in being demarcated among the rest of the dead.

\section{Religious and socio-political inferences of burial evidence}

After having made a brief survey of the available data, regarding both the private and public burials, we could wonder whether the social and political differentiation expressed in the scale of funerary rites or the embellished

68 GARLAND, Greek way of death, p. 90; KURTZ-BOARDMAN, Burial customs, p. 93-94, 247-248. On $\Delta \eta \mu$ ó $\sigma$ tov $\sigma \hat{\eta} \mu \alpha$, see THUC., II, 34.5. The Academy Road was embellished with monuments that became typical of Athenian democracy; moreover, in the Demosion sema there was a juxtaposition of public and private burial, but the public graves were more elaborate (CLAIRMONT, op. cit. [n; 52],

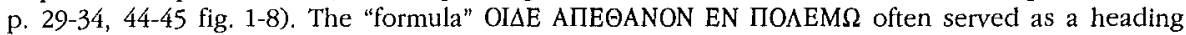
over the casualty lists (ibid., p. 48); STUPPERICH, The Arcbaeology of Athens and Attica under the Democracy, p. 96). On the funerary relief, see ClAIRMONT, op. cit. (n. 52), p. 74.

69 GARLAND, Greek way of deatb, p. 102; KURTZ-BOARDMAN, Burial customs, p. 99-100, 257-258. Cenotaphs were erected at Plataea by those who did not participate in the fight against the Persians. The latter were so ashamed of not having given their support to this war that a cenotaph solved their bad conscience [HDT., IX, 85; CLAIRMONT, op. cit. (n. 52), p. 16]. C. Clairmont assumes a cenotaph in the Demosion Sema for the casualties at the Arginousai ( $406 \mathrm{BC}$.); the Athenians were angered against the generals who neglected to pick up the shipwrecked (XEN., Hell., I, 7, 11; ibid., p. 17).

70 KURTZ-BOARDMAN, Burial customs, p. 110.

71

Ibid., p. 97, 190-191. 
architecture had any influence on the religious beliefs, hidden behind the burial behaviour.

Concerning the private burials, the conclusion that stems from the above discussion is that in Ancient Greece, the choice of the burial facility, the disposal of the dead and the grave goods were practices with both religious and social overtones. The detected differentiation at Ramnous, Argos, Sparte and other sites as far as it concerns the type of burial confirms this suggestion.

We have already explained that the Greeks' concern with what was disposed after death was never great; on the contrary, their concern with funerary architecture and burial rites were considerable ${ }^{72}$. The Attic periboloi imply that the major occupation of an ordinary Athenian was to provide his dead relatives with a secure resting-place where the bonds of kinship could be observed. The peribolo $i$ do not reflect any pious devotion towards the dead but served as a means of demonstrating the strength of family tradition. The peribolos was above all a status symbol. In this context, the arrangement of the monuments fronting the roadside and the use of symbols of powers (lions, dogs etc.) are of interest ${ }^{73}$.

Still, it is important to note that even if the funerary legislation limited the energy expended in mortuary practices, there is no evidence for a massive shift in the funerary beliefs which would have caused these changes in the burial ${ }^{74}$.

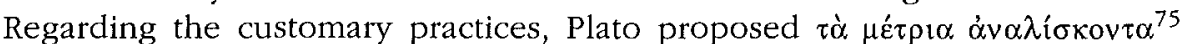
Thus, unlike the exaggerated funerary practices, which sometimes were transformed to $\ddot{\beta} \rho \imath \varsigma$, the philosopher suggested the moderation ( $\mu \varepsilon \dot{\tau} \tau \circ \nu$ ) and brought about a reconciliation between the sacral duties of the citizens towards the dead and the state legislation. $M$. Alexiou rightly argues that the restrictions, detected in the funerary legislation of the sixth century originated in the advanced city states where a new democratic society was establishing itself. The exception is Sparte, where full ceremony was maintained for the funeral of kings, so that restriction was selective and related to social inferences ${ }^{76}$.

On the other hand, the term cult of the dead or tomb cult, which is disseminated in the relevant bibliography ${ }^{77}$, lets us concluding that the dead were considered as divine powers. But was this the case in Ancient Greece? It is feasible that the practice of funerary rites involved the use of the pottery found

72 Ibid., p. 329.

73 GARLAND, $A B S A, 77$ (1982) p. 131. On the sculptured animals, see C. VERMEULE, Greek funerary animals, 450-300 BC., in $A J A, 76$ (1972), p. 49-59. Besides, BOARDMAN claims that many grave goods were determined by the desire of the kin to display their grief (Burial customs, p. 332). S. HUMPHREYS thinks that the visits to the tombs of famous ancestors in Classical period was not a pious duty but a way of reminding contemporaries of the glory of one's own family (art. cit. [n. 13], 123).

74 MORRIS, Death in Classical antiquity, 147-149.

75 Plato, Pbed., 115c-116; see also X. DE SCHUTTER, att. cit. (n. 47), p. 63.

76 ALEXIOU, op. cit. (n. 15), p. 17.

77 WHITLEY, art. cit. (n. 33), p. 218; HUMPHREYs, art. cit. (n. 13). 
in the "offering trenches". It seems therefore that the living honoured and respected the dead. However, there is no specific evidence that these trenches were associated with the practice of any cult activity, performed in honour of a divine power. Thus, these trenches differ from the cultic installations (altars), found at formal shrines ${ }^{78}$. Moreover, the foodstuff found in the graves were all presumably offered for the benefit of the dead. But animal sacrifice, as to a hero, only became appropriate once the dead were divined. This kind of evidence is literary ${ }^{79}$.

We could therefore reach the conclusion that the honours accorded to the dead had not as purpose to induce them to affect the living or contribute to their survival. Consequently, there is no inference to a cult of the dead as divine power. C. Antonaccio rightly argues that the Greeks practised a kind of memorialism rather than ancestor worship. They remembered the dead members of their family but did not divinize them ${ }^{80}$. In addition, some practices conducted on behalf of the Greek dead were not always inspired by genuine piety ( $\varepsilon \dot{\sigma \varepsilon} \beta \varepsilon \varepsilon \alpha$ ) but had also political implications. Thus, following the defeat of the Persian invasion in Greece, Themistokles persuaded the state to build a defensive wall around the city. The re-use of Archaic graves for this project implies that such "objects" were not considered as sacred".

On the other hand, $\sigma \omega \varphi \rho \circ \sigma o v \eta \eta$ was a civic virtue and the ordinary men were commemorated as $\sigma \omega ́ \varphi p o v \varepsilon \varsigma$ by archaic stelai ${ }^{82}$. Still, we should agree with A. Shapiro that the finest Athenian virtues were courage and loyalty, in short $\kappa \alpha \lambda_{\text {o } \alpha} \alpha \alpha \theta$ í $\alpha$. The war casualties were the perfect exemplars of $\alpha{ }^{\prime} \delta \rho \varepsilon \varsigma$ $\gamma \varepsilon v$ ó $\mu \varepsilon v o 1 ~ \alpha \gamma \alpha \theta$ oi (good men); these men, while alive, would never achieve the status of heroicised citizen ${ }^{83}$.

$78 \mathrm{~J}$. WHITLEY claims that the "offering trenches" should not be associated with the funeral ceremony but they resemble to cult offerings. The ceramic items, such as an oinochoe depicting mourning women, found in the trenches should have been made especially as "funerary votive" (art. ctt. [n. 33], p. 218). However, the expression of grief by means of "mourning iconography" is not necessarily related to any cult activity. On the other hand, since some monuments depicted on Attic lekythoi of the 5th century do not conform to the forms of grave markers or stelai, D. Rupp identifies them as altars of funerary shrines for the dead 'heroes' of a family; still, he recognises that they could be used in funerary rituals for ordinary individuals (D. RUPP, Altars as funerary monuments on Attic wbite lekytboi, in AJA, 84 [1980], p. 524-527).

79 KURTZ-BOARDMAN, Burial customs, p. 215.

80 C. ANTONACCIO, Contesting the Past: Hero Cult, Tomb Cult and Eplc in Early Greece, in $A J A, 98$ (1994), p. 401. On the treatment of Mycenaean tombs in the Iron Age and after, see C. ANTONACCIO, Placing the Past: the Bronze Age in the Cultic Topography of Early Greece, in S.E. ALCOCK, R. OSBORNE (eds.), Placing the Gods. Sanctuaries and Sacred Space in Anctent Greece, New York 1994, p. 90-92.

81 GARLAND, Greek way of deatb, p. 121-122.

$82 I G ., \mathrm{I}^{2}, 1058 ; I G ., \mathrm{II}^{2}, 11162$; HUMPHREYS, att. ctt. (n. 13), p. 114.

83 On the relationship of polis to religion, see H.A. SHAPIRO, Religion and Politics in Democratic Atbens, in W.D.E. COULSON, O. PALAGIA, T.L. SHEAR, H.A. SHAPIRO, F.J. FROST (eds.), The Archaeology of Athens and Attica under the Democracy. Proceedings of an International Conference celebrating 2500 years since the bith of democracy in Greece, beld at the American 
Since the fallen warriors became public heroes, it is feasible that they received special honours by the state. While we hold this perspective, we could wonder whether they were also elevated to the status of divined heroes $^{84}$.

In fact, distinctions can be made between the two senses of the term bero in Ancient Greece: there was the secularised term for the war casualties and the religious term, associated with honoured dead, residents in the land and tied to a particular locality ${ }^{85}$. The concept of the hero as a semi-divine figure was extended to Mycenaean rulers, as founders of later Greek families ${ }^{86}$. The earliest written reference to a cult of heroes (veneration of their relics) dates to the 7 th century, when the lawgiver Drakon prescribed that gods and local heroes should be honoured together according to ancestral customs ${ }^{87}$. L. Farnell, in his study about the cults of ancestors, points out that the hero in the Greek religious sense was a person whose virtue, influence or personality was so powerful in his lifetime that after death, he was considered as a supernormal power, claiming to be venerated ${ }^{88}$.

However, there is no direct evidence that the fallen warriors were regarded as semi-divine powers, claiming to be worshipped and propitiated; the established religious ideas concerning death would remain unchanged for both the ordinary citizens and the war dead. In funeral speeches, the casualties of war were addressed as ones who had departed to the islands of the Blessed ${ }^{89}$.

Scbool of Classical Studies at Athens (4-6 December 1992), 1994 (Series Oxbow Monographs, 37), p. 123-129. On the appellation of war dead, see $S I G^{3}, 1225$ (Rhodes, 3rd century BC.).

84 For such a suggestion, see CLAIRMONT, op. cit. (n. 52), p. 23.

85 WHITLEY, art. cit. (n. 33), p. 219.

86 Towards the end of the Geometric period, Greeks showed a sudden interest in making offerings at graves of their predecessors; the graves belonged to an age between 500 and 1000 years earlier. In this case, the worshippers could not have the faintest notion of the real identity of the people buried in these graves. A. Snodgrass suggests that at a time when the Greeks were establishing a society "in which land-ownership was the secure path to citizenship", establishing a link with a territory through the medium of its earlier inhabitants would be helpful (A. SNODGRASS, Archaeology and the Rise of the Greek State, Cambridge, 1977, p. 30-31). Recently, C. Antonaccio argued that the veneration of ancestors occurs as early as the 10th century $\mathrm{BC}$, and continues beyond the emergence of the polis, while the popularity of hero cult changes between the $8 \mathrm{th}$ and early 5th centuries BC., in response to political change (C. ANTONACCIO, in $A J A, 98$ [1994], p. 402403).

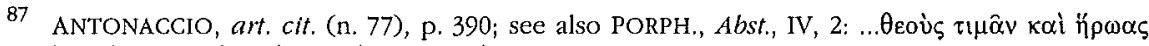

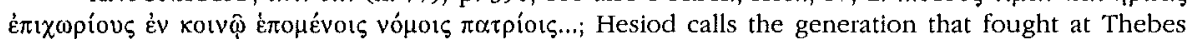
and Troy $\dot{\eta} \mu \hat{i} \theta$ eot (for further discussion and bibliographical references, see ANTONACCIO, ant cit. [n. 77], p. 406).

88 FARNELL, op. cit. (n. 9), p. 343. On the other hand, Stupperich points out that the $\dot{\eta} \rho \hat{\omega} \alpha$ did not differ a lot from the rest of the graves: they were associated with neither a sanctuary nor an altar; still, they were provided with an open-air "temenos" and a "bothros", designated for the blood libations (STUPPERICH, Staatsbegrabnis, p. 61).

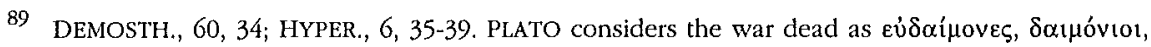

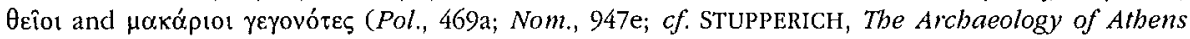
and Attica under the Democracy, p. 98). The war dead lived without cares in the Blessed Isles as

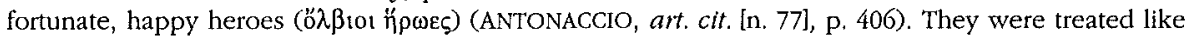


Another important question to answer is whether every citizen, especially in Attica, received a formal burial or if formal burials were restricted to certain persons. In fact, slaves were entitled to be buried but, to judge from the literary sources, the Greeks did not consider that a slave had expectation of after life, so mortuary ritual and grave goods were not necessary ${ }^{90}$. In this case, the religious beliefs concerning death were associated with the social status. This suggestion is reinforced by the fact that according to the textual evidence, the slaves were entitled to receive the funeral honours of free men, only by dying in battle. Still, they could not share the honours of heroicised citizens ${ }^{91}$. It seems therefore that the slaves, by means of their heroism, were elevated to the level of a free man and entitled to receive the burial rites; consequently, judging from a religious point of view, they were made equal to every human being. Still, judging from a political point of view, despite their sacrifice, they never achieved the status of heroicised citizens.

\section{Conclusion}

By way of conclusion we could argue that in Ancient Greece every man, that is to say the ordinary citizens, the slave if they achieved the status of free men and the war dead were entitled to receive the customary funerary practices, such as burial and ritual lament that originated from established religious beliefs. In addition, the state itself honoured the war dead and elevated them to the level of heroized citizens. But this heroization does not mean that the dead were turned into semi-divine powers. Ti $\mu$ iे was the communal acknowledgement of these citizens. They might be likened to the heroes, whose $\alpha \rho \varepsilon \tau \dot{\eta}$ was celebrated in the Homeric poems. But since now their $\dot{\alpha} \rho \varepsilon \tau \dot{\eta}$ served, instead of themselves, the whole polis, a new concept of glory ( $\delta$ ó $\xi \alpha$ ) also appeared ${ }^{92}$.

On the other hand, it is most important that the public funeral was organised along civic lines and the state claimed what was the right of the family ${ }^{93}$. It seems therefore that the public funerals should be a crucial part of democratic

heroes but their herolzation was never explicit; we could therefore speak about a "political motivation of heroization" (STUPPERICH, ibid., p. 98, 100; CLAIRMONT, op. cit. [n. 52], p. 14).

90 KURTZ-BOARDMAN, Burial customs, p. 198. It was quite acceptable to bury the domestic slaves within a family enclosure (GARLAND, $A B S A, 77$ [1982], p. 130).

91 KURTZ-BOARDMAN, Burlal customs, p. 198-199. Even if in the sixth century, the slaves who fought faithfully were buried with their masters in the state burial, after Marathon the slaves were buried in a separate tomb. On the slaves' burials mainly in Hellenistic period, see H. RAFFEINER, Sklaven und Fretgelassene: eine soziologiscbe studle auf Grundlage des griechiscben Grabepigramms, Innsbruck, 1977 (Commentationes aenipontanae, XXIII).

92 ShAPIRO, AJA, 95 (1991), p. 632; WHITLEY, art. cit. (n. 33), p. 229. On the change from the epic ideals to democratic ethics see, STUPPERICH, Staatsbegrabnis, p. 63. On the notion of $\tau$. see ANTONACCIO, art. cit. (n. 77), p. 397.

93 Although the tombs of war dead were not part of the family plot, they were adorned with hero-like glamour (STUPPERICH, art. cit. [n. 89], p. 100). 
ideology which might have helped to the creation of a communal ideal. The public monumental graves should be primarily political monuments, connected with collective identity. Nevertheless, it is generally accepted that a political and religious change occurred in Archaic Attica; in 7th century, Attica was dominated by aristocracy, whereas the 6th century is seen as the major period of reorganisation. The new democracy required new heroes. The war dead

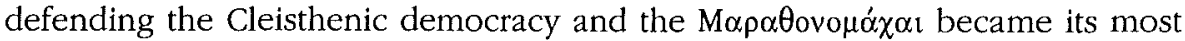
characteristic representatives ${ }^{94}$.

Finally, in democratic Athens, even death could be a political issue ${ }^{95}$.

B. P. 19045

Eleni GEORGOULAKI

GR - 11710 ATHÈNES

94 WHITLEY, art. cit. (n. 33), p. 213, 226-227; on the archaic aristocracy, see also SHAPIRO, AJA, 95 (1991), p. 644. On democracy, see MORRIS, Anctent society, 210; MORRIS, Death in Classical antiqulty, 128-138; STUPPERICH, ait. cit. (n. 89), p. 93; STUPPERICH, Staatsbegräbnis, p. 64-65. On cult and politics in Archaic Attica, see R. OsBORNE, Archaeology, the Salaminiol, and the Politics of Sacred Space in Arcbaic Attica in S.E. ALCOCK, R. OSBORNE (eds.), Placing the Gods. Sanctuaries and Sacred Space in Ancient Greece, New York, 1994, p. 147-154. Funerary inscriptions in Classical Athens emphasised citizenship and denied social divisions within the polis; thus they provided an idealised representation of the social order. In this case, the funerary practices allow

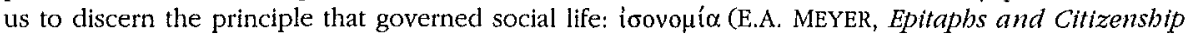
in Classical Atbens, in JHS, 103 [1993], p. 112-119).

95 Public war burials were sometimes abused and served as a means to an end: the soldiers were promised to receive a magnificent burial, if they demonstrated their heroism in the battle (XÉN., Hell., VI, 1, 6). Besides N. Loraux argues that the Greek city-states expressed both their political and cosmotheoretical status through the burial customs they practised. Sparte exhibited an hierarchic concept, Athens proclaimed the idea of equality before death (N. LORAUX, $H A \theta \dot{\eta} v \alpha, o$

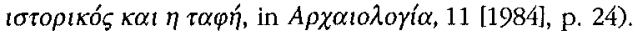



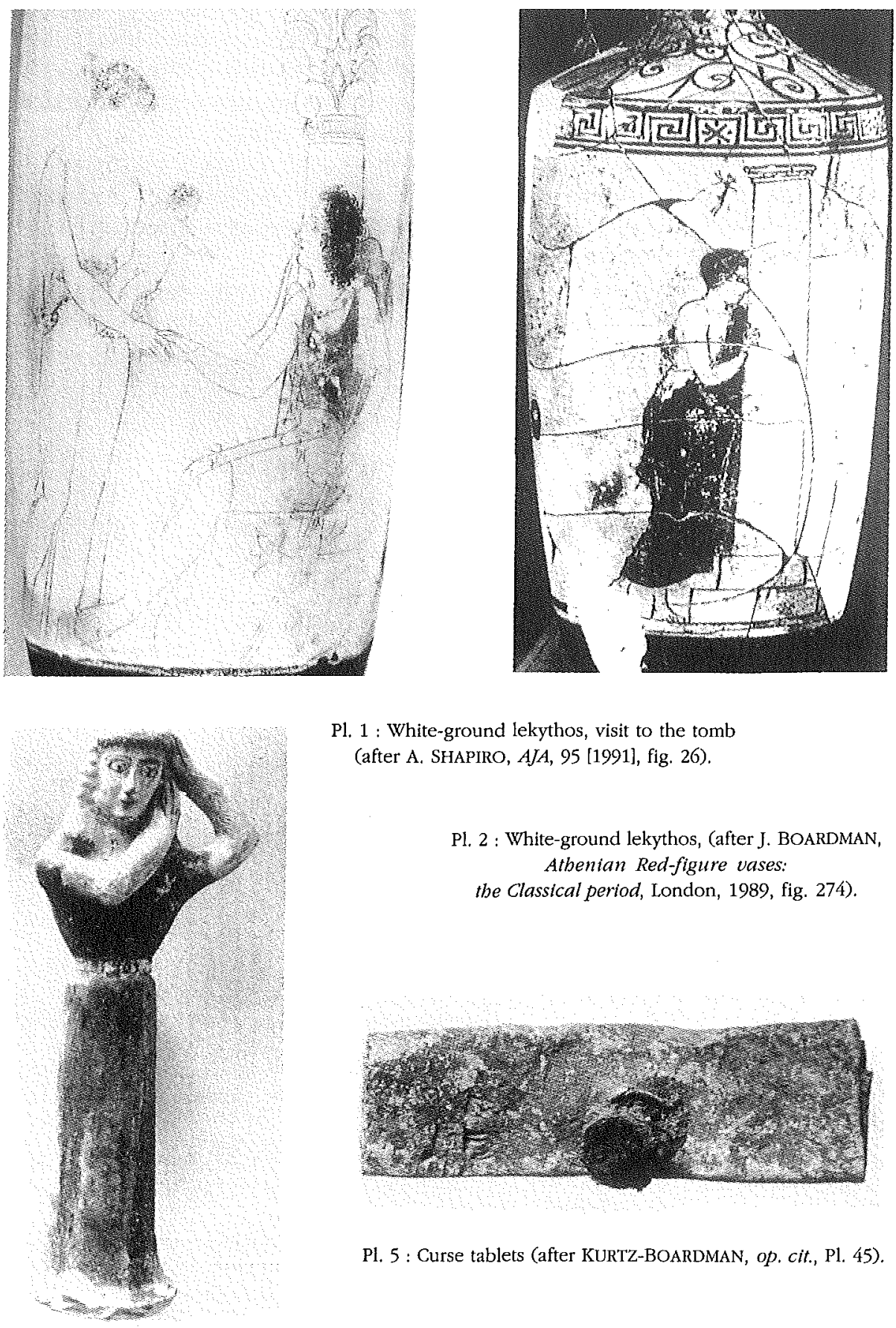

Pl. 1 : White-ground lekythos, visit to the tomb (after A. SHAPIRO, $A J A, 95$ [1991], fig. 26).

Pl. 2 : White-ground lekythos, (after J. BOARDMAN, Atbenian Red-figure vases:

the Classical period, London, 1989, fig. 274).

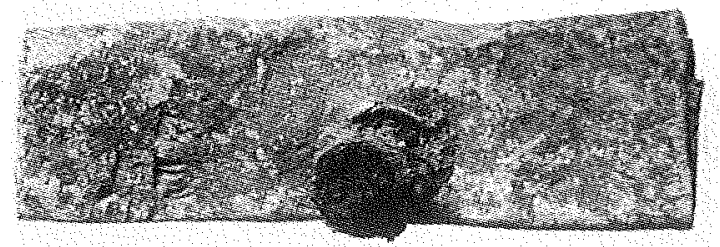

Pl. 5 : Curse tablets (after KURTZ-BOARDMAN, op, cit., Pl. 45).

Pl. 3 : Archaic mourning female figure from a Thera grave

(after D.C. KURTZ-J. BOARDMAN, Burial customs, Pl, 43). 


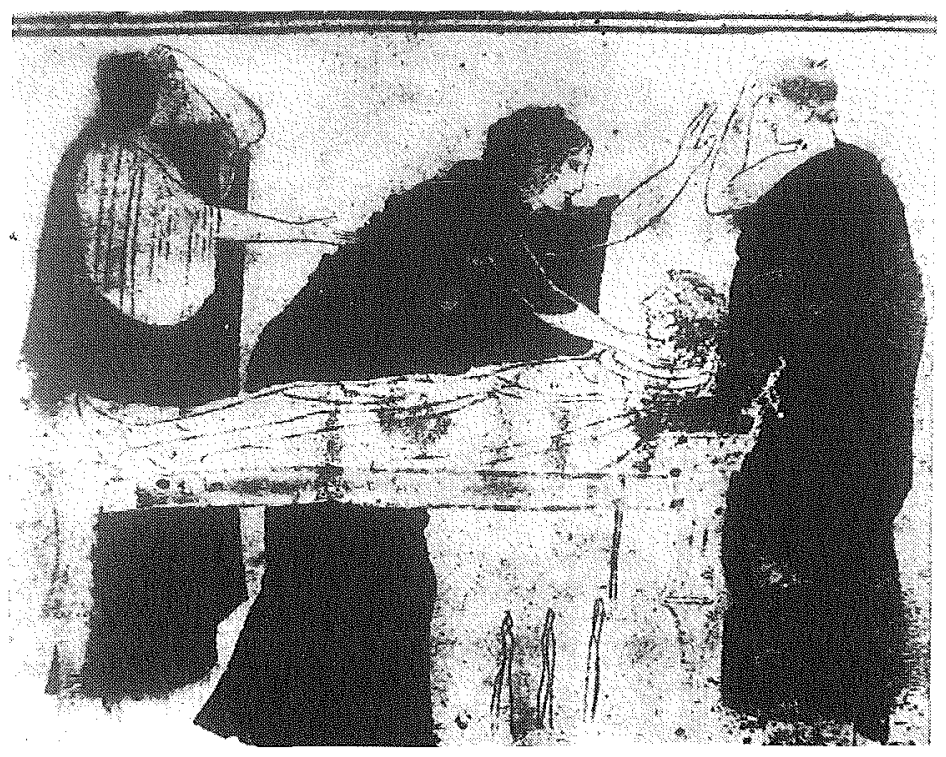

P1. 4 : White-ground lekythos, (after BOARDMAN, op. cit., fig. 256).

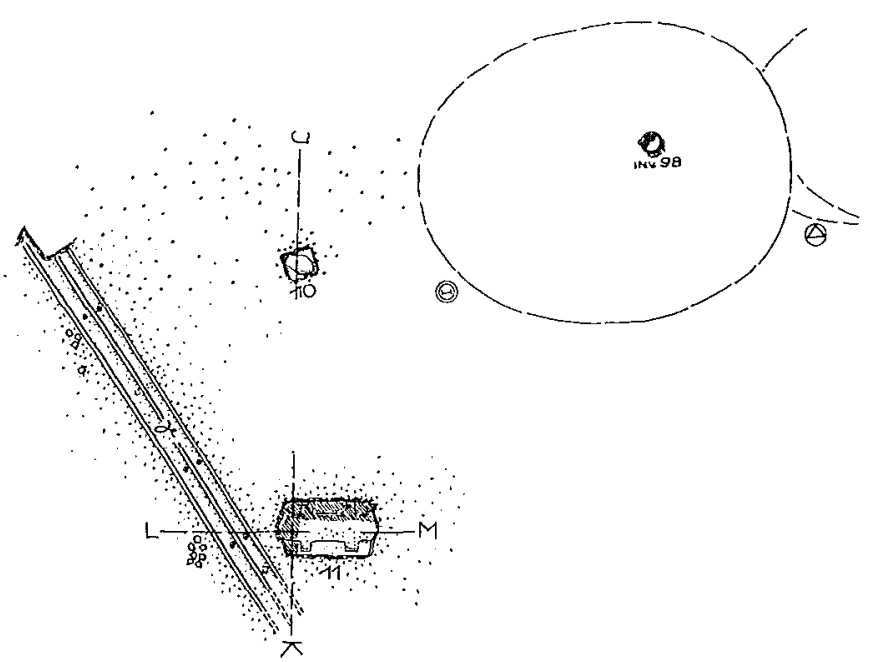

Fig. 1 : Offering trench $\gamma$, in the Kerameikos cemetery, associated with grave 11 (after J. WHITLEY, $A J A, 98$ [1994], fig. 3). 


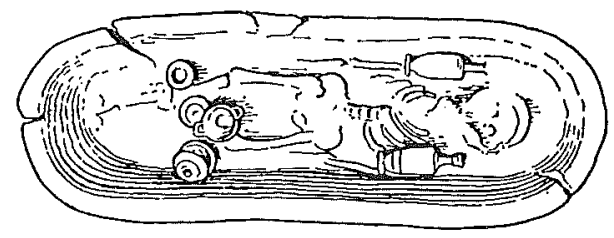

Fig. 2 : Child larnax (after KURTZ-BOARDMAN, op, cit, fig. 17).

Fig. 3 : Reconstruction of an archaic monumental grave marker (after G.M.A. RICHTER, Archaic Attic Grave stones, Cambridge Mass., 1944, fig. 9).
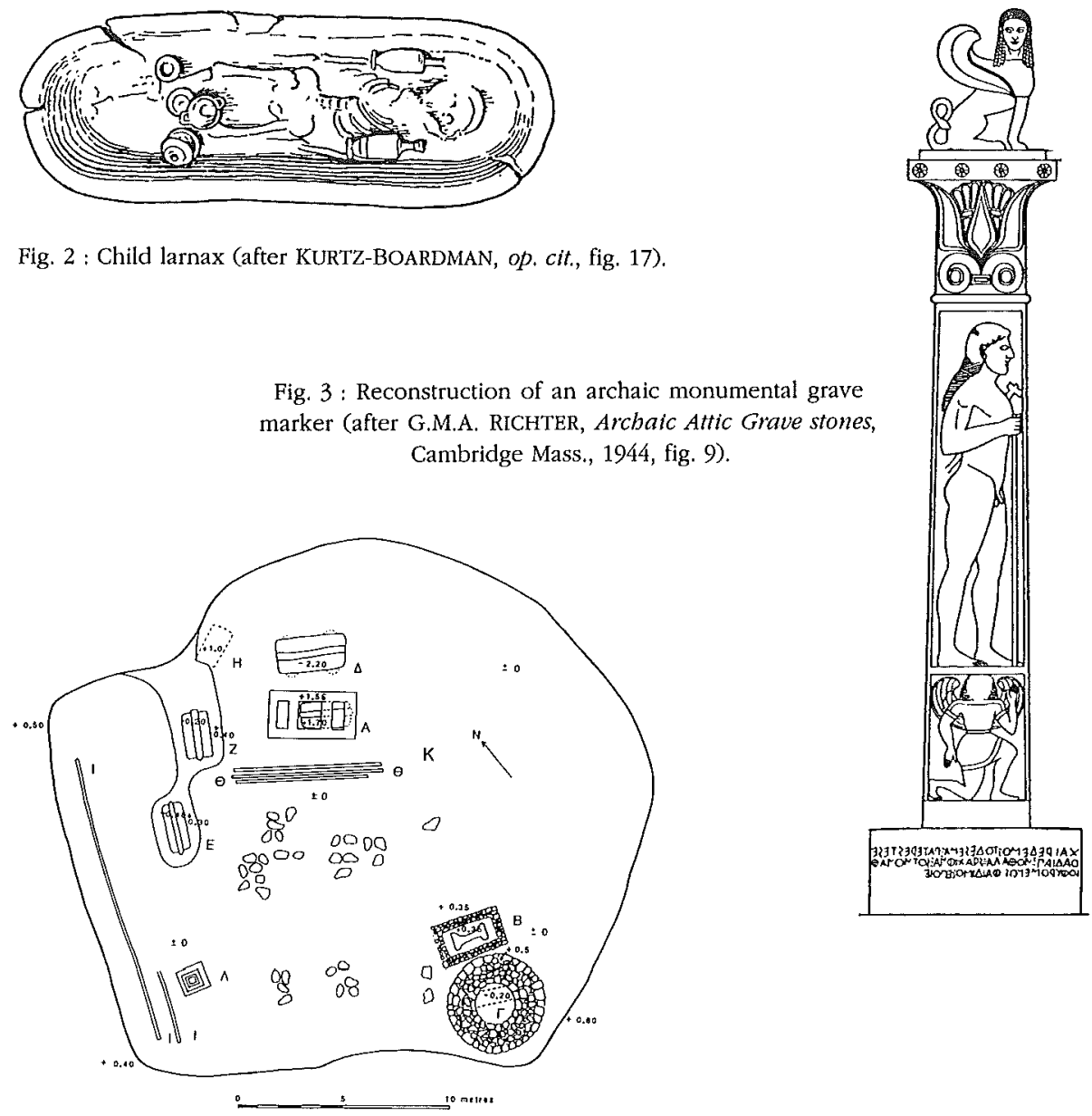

Fig. 4 : The grave complex at Vourva. The offering trench is marked by the horizontal bars labeled $\theta$ on either side (after J. WHITLEY, art. cit., fig. 2).

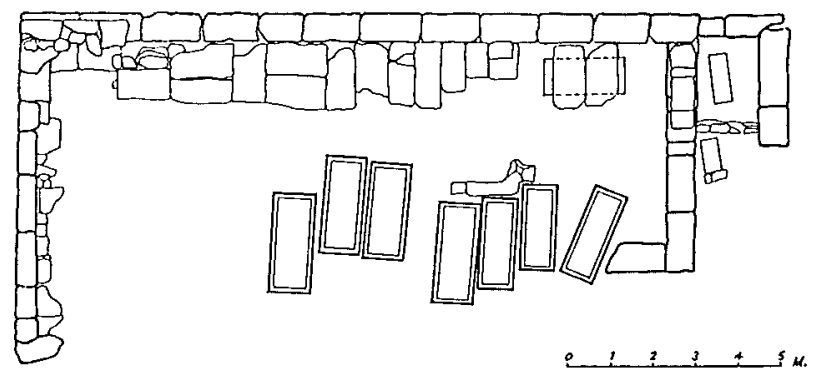

Fig. 6 : Attic peribolos tomb (after KURTZ-BOARDMAN, op. cit., fig. 19). 


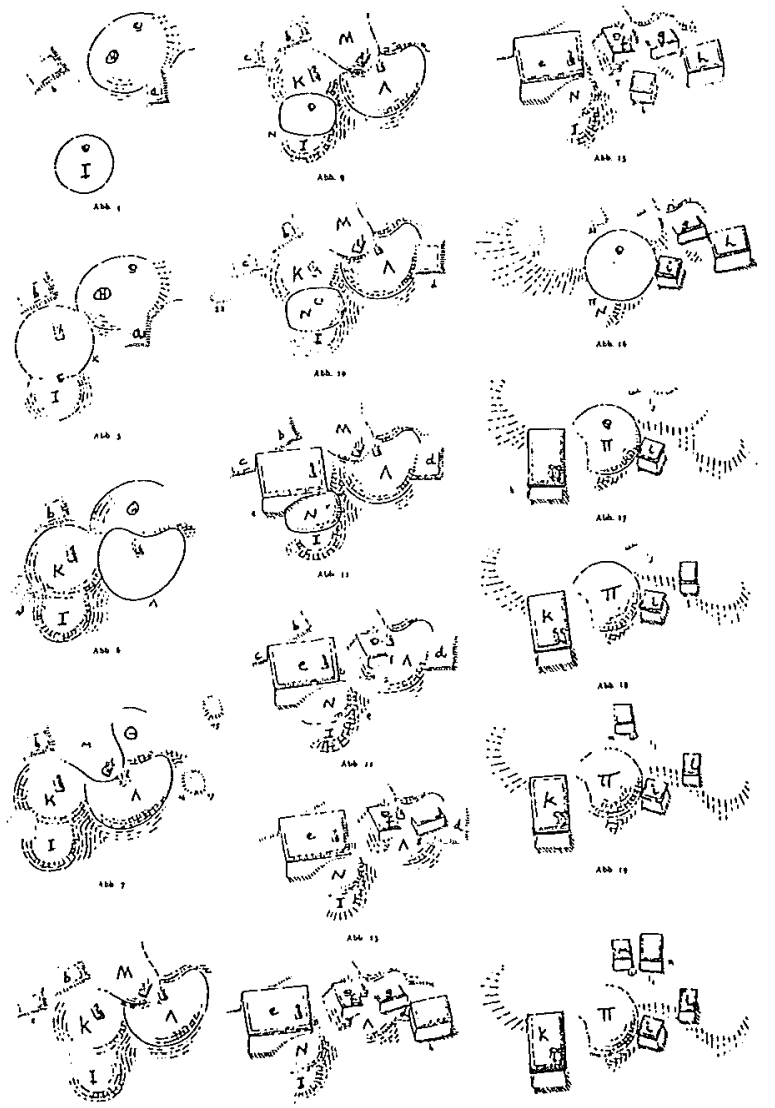

Fig. 5 : Kerameikos cemetery; development of mounds and built tombs on a single site, c. 650-570 B.C. (after S. HUMPHREYS, JHS, 100 [1980], fig. 1).

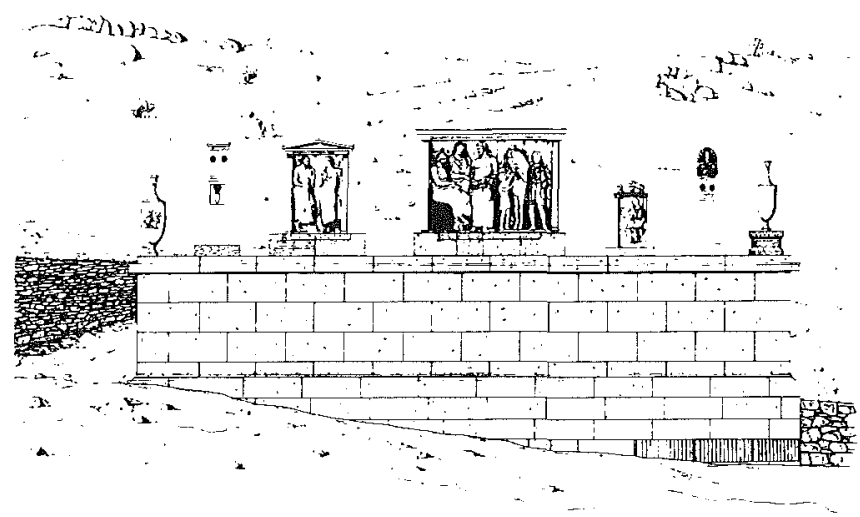

Fig. 7 : Reconstruction of Hierokles peribolos at Ramnous (after V. PETRAKOS, in Ergon 1992, fig. 6). 

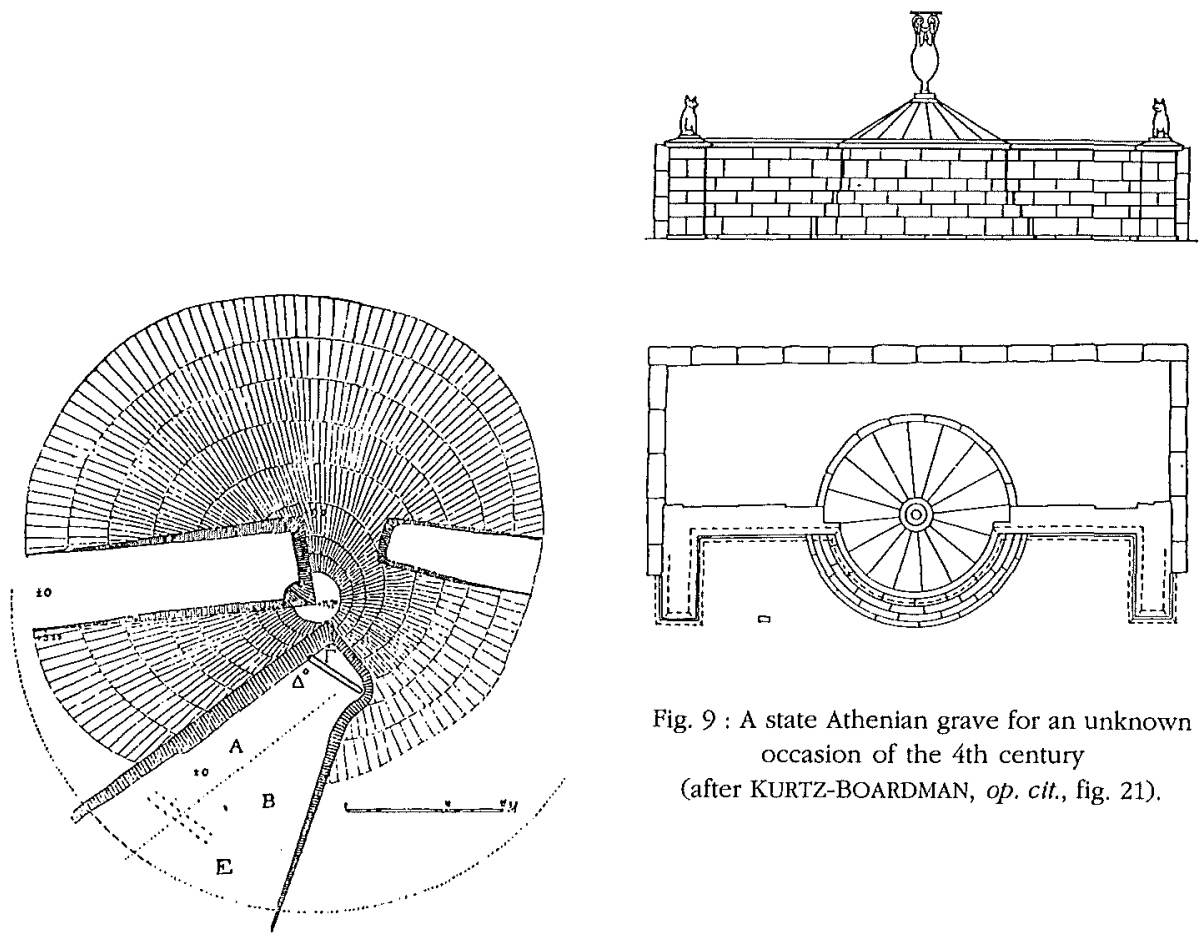

Fig. 8 : Plan of the Marathon mound, $\mathrm{E}$ is the offering trench and $\Delta$ the cremation tray (after J. WHITLEY, art. cit., fig. 1).

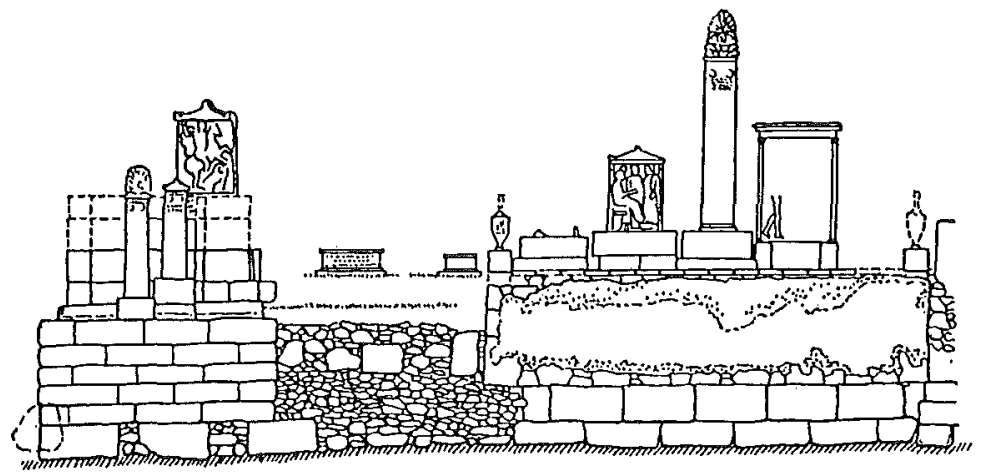

Fig. $10:$ Grave plots along the West Road of the Kerameikos in Athens. That on the left is of Dexileos (after KURTZ-BOARDMAN, op. cit., fig. 20). 